\title{
ACUTE TOXICITY EVALUATION OF ETHANOL EXTRACT OF CURCUMA MANGGA RHIZOME
}

\author{
YUANDANI*, EDY SUWARSO
}

Department of Pharmacology, Faculty of Pharmacy, Universitas Sumatera Utara, 5 Jalan Almamater, USU-Kampus, Medan 20155, Indonesia. Email: yuan_dani@yahoo.com

Received: 16 November 2016, Revised and Accepted: 16 December 2016

ABSTRACT

Objective: Curcuma mangga is highly valued in traditional medicines. This study was carried out to evaluate the in vivo acute toxicity of $C$. mangga.

Methods: Acute toxicity of ethanol extract of $C$. mangga rhizome was evaluated in mice. The extract at a single dose of 500, 1000, 2000 and 5000 mg/kg body weight (BW) were orally administered to the test animal. Signs of toxicity, BW and mortality were observed for 14 days. The macropathology and histopathology examination was also performed.

Results: The highest dose administered (5000 mg/kg BW) did not produce mortality of the test animals. Hence, the lethal dose 50 of ethanol extract of $C$. mangga was estimated to be more than $5000 \mathrm{mg} / \mathrm{kg}$. No sign of toxicity was observed except lethargy. All the organs displayed normal color and texture. Histopathological examination did not show any lesion except for highest dose.

Conclusion: The results indicate the safety of ethanol extract of $C$. mangga rhizome to the animal tested. Therefore, this plant can be used as a safe and effective alternative medicine.

Keywords: Curcuma mangga, Acute toxicity, Mortality.

(C) 2017 The Authors. Published by Innovare Academic Sciences Pvt Ltd. This is an open access article under the CC BY license (http://creativecommons. org/licenses/by/4.0/) DOI: http://dx.doi.org/10.22159/ajpcr.2017.v10i1.16196

\section{INTRODUCTION}

Discovering and developing safe and effective drug should be carried out as our knowledge of disease increases. There is no doubt that natural products have been important sources of drugs. Most of the drugs used in clinical practice are directly or indirectly derived from natural sources and they will always be one of the main source of new pharmaceutical compounds $[1,2]$. It is believed that about $80 \%$ of the plants are being used by world population as their main source of medicinal agents [1].

Since ancient times, focus on use of traditional herbs as alternative treatment has been revived all over the world. Along this path, plants from family Zingiberaceae have been widely used in folk remedies. Among them, Curcuma species revealed various biological activities. Curcuma mangga is one of the important plant in this genus. It can be found in most tropical countries such as Indonesia, Malaysia, and Thailand [3]. C. mangga is locally known as "temu mangga" in Indonesia and is highly valued in folk medicine for its healing properties to treat stomach disorders, fever, and cancer-related diseases [4].

Phytochemical studies on C. mangga have resulted in the isolation of various compounds, including $\beta$-sitosterol,curcumin, $(E)$-labda-8(17),12dien-15,16-dial, zerumin A (E)-15,16-bisnorlabda-8(17),11-dien-13one, demethoxycurcumin and bisdemethoxycurcumin $[4,5]$. C. mangga has been reported to have analgesic and anti-inflammatory activities [6]. Rhizome of $C$. mangga showed cytotoxic activities against hormonedependent breast cell line (MCF-7), nasopharyngeal epidermoid cell line (KB), lung cell line (A549), prostate cancer-3, cervical cell line (Ca Ski), colon cell lines (HCT 116 and HT-29) [5,7]. It also displayed antioxidant and antifungal activities [8,9]. However, little is known about the toxic effect of ethanol extract of $C$. mangga in mice. In this study, ethanol extract of $C$. mangga was investigated for its acute effect in mice especially the examination on body weight (BW), mortality, macropathology and histopathology. The results of this study may provide some insights on the possibility of this plant as a safe alternative medicine and to be developed as a new drug.

\section{METHODS}

\section{Chemicals and reagents}

The chemicals used in this study were ethanol (SmartLab, Indonesia) natrium carboxymethylcellulose (Na CMC) (Sigma, USA), and formaldehyde (SmartLab, Indonesia). Light microscope (Boeco, Germany) was also used in this study.

\section{Plant materials}

The rhizomes of C. mangga were collected from Medan, Sumatera Utara, Indonesia. Then, the plant was authenticated in Herbarium Medanense, Universitas Sumatera Utara, Indonesia.

\section{Extraction procedure}

The plant materials were allowed to dry under shade. $350 \mathrm{~g}$ of dried material of plant sample was ground and macerated in ethanol at the ratio of 1:10 (w/v). The extraction was repeated twice on the residue. The filtrates were combined and the solvent was removed under reduced pressure to obtain extract of C. mangga $(38.4 \mathrm{~g}, 10.95 \% \mathrm{w} / \mathrm{w})$.

\section{Acute toxicity study}

A total of 30 male mice weighing between 15 and $35 \mathrm{~g}$. The animals were placed in clean and dry cages with good ventilation. Mice were given pelletized commercial mice food and tap water ad libitum. The animals were allocated to six groups of five mice each. The control group received Na CMC $0.5 \%$ as vehicle. Meanwhile, C. mangga extract was dissolved in Na CMC $0.5 \%$ administered orally (only once) at a single dose of 500, 1000, 2000 and $5000 \mathrm{mg} / \mathrm{kg}$ BW. Observation was carried out according to OECD guideline [10]. Mice were observed for 14 days, $4 \mathrm{hrs} /$ day. The mice were weighed at day 0,7 and 14 . Visual observations for mortality and signs of toxicity (salivation, lethargy, diarrhea, and coma), were conducted during the period. At the end of the experiment, the mice were sacrificed and the organs were excised 
and examined macroscopically. Principal vital organs (liver and kidney) were preserved in a fixation medium of $10 \%$ solution of buffered formalin for histopathological study. The use of mice was approved by the Animal Research Ethics Committees of Universitas Sumatera Utara (approval number 599/KEPH-FMIPA/2016).

\section{Statistical analysis}

The data were analyzed using Statistical Package for Social Sciences version 15.0. Each sample was measured in triplicate and the data presented as mean \pm standard error of the mean. Data were analyzed using a one-way analysis of variance for multiple comparisons. $\mathrm{p}<0.05$ was considered to be significantly different.

\section{RESULTS}

\section{Signs of toxicity}

The observation of signs of toxicity such as salivation, lethargy, diarrhea, and coma was conducted for 14 days. Of all the signs of toxicity, only lethargy was observed at the doses of 2000 and $5000 \mathrm{mg} / \mathrm{kg} \mathrm{BW.}$

\section{BW measurement}

The monitoring of BW changes of the animals tested is important to evaluate the effect of extract on the metabolic status of the animals. In this study, none of the animal tested suffered weight loss as shown in Table 1. All the treatment groups displayed weight gain, so did the control group. Average daily gain of all the treatment and control groups were statistically significant $(\mathrm{p}<0.05)$. However, the weight gain shown by all the animals followed a general trend, there was no overweight gain. The result suggests that the ethanol extract of $C$. mangga did not induce deleterious effects on the general health status and metabolic growth of the mice.

\section{Mortality}

There was no mortality observed during experimental period (14 days). The result assumed that the oral lethal dose $50\left(\mathrm{LD}_{50}\right)$ of ethanol extract

Table 1: Effect of ethanol extract of C. mangga on BW of mice (Mean \pm SEM)

\begin{tabular}{|c|c|c|c|c|c|}
\hline \multirow[t]{2}{*}{ Day } & \multicolumn{5}{|c|}{ BW (g) \pm SEM } \\
\hline & Control & $500 \mathrm{mg} / \mathrm{kg}$ & $1000 \mathrm{mg} / \mathrm{kg}$ & $2000 \mathrm{mg} / \mathrm{kg}$ & $5000 \mathrm{mg} / \mathrm{kg}$ \\
\hline 0 & $20.1 \pm 3.1$ & $17.8 \pm 0.2$ & $18.9 \pm 0.4$ & $20.3 \pm 0.1$ & $15.5 \pm 0.9$ \\
\hline 7 & $32.6 \pm 0.6^{*}$ & $18.6 \pm 0.4^{*}$ & $24.8 \pm 0.4^{*}$ & $26.0 \pm 0.5^{*}$ & $20.4 \pm 0.5^{*}$ \\
\hline 14 & $33.2 \pm 0.9 *$ & $19.9 \pm 0.8^{*}$ & $30.7 \pm 0.8^{*}$ & $31.8 \pm 0.9^{*}$ & $25.2 \pm 0.8^{*}$ \\
\hline
\end{tabular}

${ }^{*} \mathrm{p}<0.05$ compared to day 0 of each group $(n=5)$. BW: Body weight,

SEM: Standard error of mean, C. mangga: Curcuma mangga of $C$. mangga rhizome was $>5000 \mathrm{mg} / \mathrm{kg} \mathrm{BW}$. Indicating, $C$. mangga is a safe alternative medicine. Toxic symptoms and mortality indicate the safety level of a substance [11].

\section{Macroscopic and microscopic examinations}

Macropathology and histopathology determinations were conducted at the end of the experiment. Liver and kidney (right and left) of mice were observed. The color and texture of all organs of treatment groups were comparable to those of control group. All the organs displayed normal color and texture. The microscopic evaluation of the liver and kidney of treatment groups at dose 500,1000, and $2000 \mathrm{mg} / \mathrm{kg} \mathrm{BW}$ did not show any lesion (data not shown). However, histopathological examination on tissues section of highest dose ( $5000 \mathrm{mg} / \mathrm{kg} \mathrm{BW}$ ) showed a little bit histopathological changes as compared to control group. Sinusoidal dilation was observed on the liver as shown in Fig. 1. In addition, glomerular lesion was also noted on right kidney as well as interstitial inflammation, but normal histopathological on left kidney.

\section{DISCUSSION}

Utilization of natural products with therapeutic properties is as old as human civilization. For a long period of time, minerals, plants, and animal products were the main sources of drugs with different properties [12]. Today, many natural plant products and synthetic compounds have been evaluated for their biological activity. Despite widespread use, few scientific studies have been undertaken to ascertain the safety and efficacy of traditional remedies.

This study focused on the acute toxicity evaluation of the ethanol extract of $C$. mangga rhizome. The ethanol extract was selected as most of plant constituents dissolve in ethanol whether polar, semi polar or nonpolar compounds [13]. In addition, ethanol extract was the active extract as reported by previous studies on their efficacy in elucidating analgesic and anti-inflammatory activities [6]. The acute toxicity study which performs for 14 days of the ethanol extract of $C$. mangga rhizome did not cause any mortality or motor-neuronal abnormalities as well as behavioral changes in mice except lethargy.

After administration of various doses of ethanol extract of $C$. mangga BW changes was noted. BW is one of important assessment in toxicological study. It indicates metabolic and health status. In this study, all animal tested revealed normal weight gain as compared to control group. Galgani and Ravussin reported that for BW represent energy intake and energy expenditure as well as macronutrient intake and macronutrient oxidation [14]. Hence, all the animals showed energy homeostasis which is critical for the survival of species.

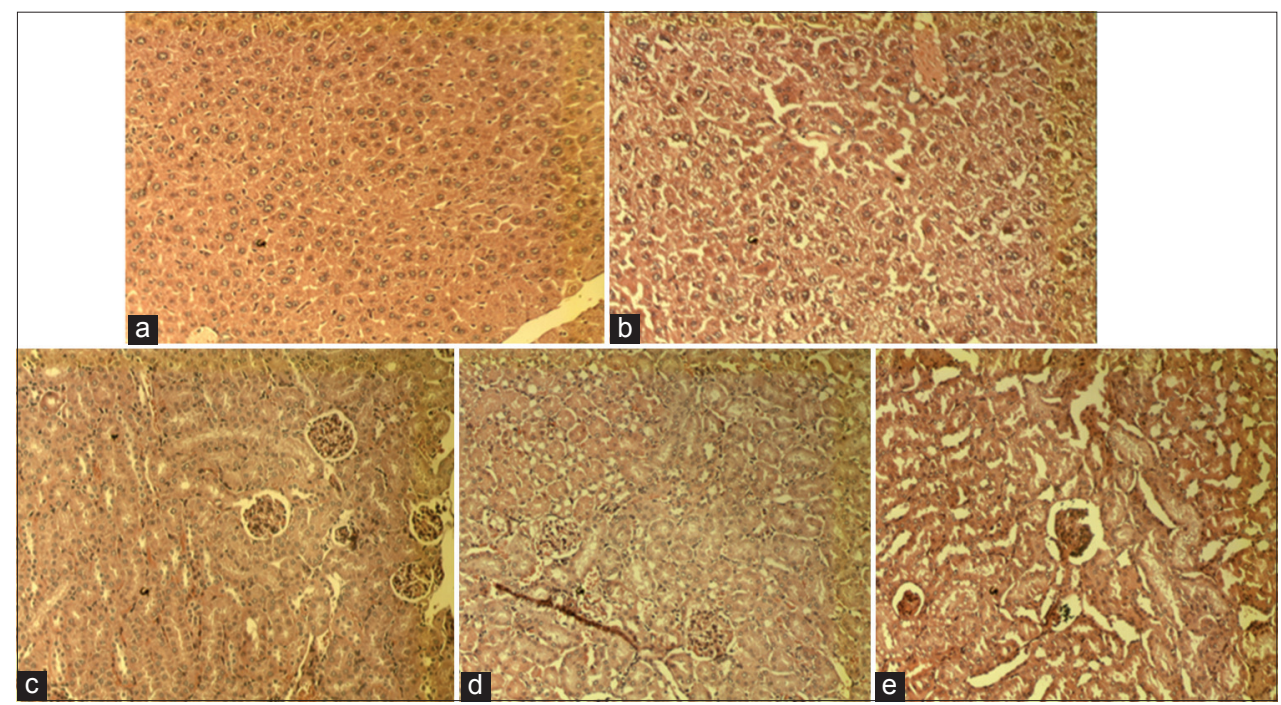

Fig. 1: Microscopic examination (10 × 25). (a) Liver of control mice; (b) liver of treatment group at $5000 \mathrm{mg} / \mathrm{kg}$; (c) $\mathrm{kidney} \mathrm{of} \mathrm{control} \mathrm{mice;}$ (d) left kidney of treatment group at $5000 \mathrm{mg} / \mathrm{kg}$; (e) right kidney of treatment group at $5000 \mathrm{mg} / \mathrm{kg}$ 
The histopathological findings showed minor effect on liver and kidney. Hepatic sinusoids and glomerular lesion were observed. Liver is an important organ in the metabolism of drugs and chemical, hence it is the most vulnerable tissue for drug toxicity [15]. Meanwhile, kidney plays an important role in drug and chemical elimination. However, macroscopic examination displayed absence of any lesions in treated mice at the terminal sacrifice indicates the harmless effect of the ethanol extract of $C$. mangga. This result was supported by none of the animal died during the study. Thus, the $\mathrm{LD}_{50}$ of ethanol extract of $C$. mangga was more than $5000 \mathrm{mg} / \mathrm{kg} \mathrm{BW}$. The result was in agreement with previous study which reported that methanol extract and hexane fraction of C. mangga have no acute toxicity [16]. Zingiber officinale, another plant from Zingiberaceae, was also reported as a safe herbal medicine with a few side effect [17]. Collectively, these data demonstrate that ethanol extract of $C$. mangga did not induce significant short-term toxicity, emphasizing its potential to be developed into a safe herbal medicine.

\section{CONCLUSION}

The highest dose administered (5000 mg/kg BW) did not produce mortality of the test animals. Hence, the $\mathrm{LD}_{50}$ of ethanol extract of C. mangga was estimated to be more than $5000 \mathrm{mg} / \mathrm{kg}$ BW. Lethargy was observed at the doses of 2000 and $5000 \mathrm{mg} / \mathrm{kg} \mathrm{BW}$. All the organs displayed normal color and texture. Histopathological examination did not show any lesion except for highest dose. The result concludes that ethanol extract of $C$. mangga is safe to use as an alternative medicine. However, subacute and chronic toxicity studies could be performed for further understanding.

\section{ACKNOWLEDGMENT}

This work was supported by University of Sumatera Utara through BPPTN research grant scheme.

\section{REFERENCES}

1. Calixto JB, Santos AR, Cechinel Filho V, Yunes RA. A review of the plants of the genus Phyllanthus: Their chemistry, pharmacology, and therapeutic potential. Med Res Rev 1998;18(4):225-58.

2. Lahlou M. The success of natural products in drug discovery. Pharmacol Pharm 2013;4:17-31. Available from: https://www.file.scirp.org/pdf/ PP_2013062411214748.pdf.

3. Hong GW, Hong SL, Lee GS, Yaacob H, Malek SN. Non-aqueous extracts of Curcuma mangga rhizomes induced cell death in human colorectal adenocarcinoma cell line (HT29) via induction of apoptosis and cell cycle arrest at G0/G1 phase. Asian Pac J Trop Med 2016;9:8-18.

4. Malek SN, Lee GS, Hong SL, Yaacob H, Wahab NA, Faizal Weber JF, et al. Phytochemical and cytotoxic investigations of Curcuma mangga rhizomes. Molecules 2011;16(6):4539-48.

5. Abas F, Lajis NH, Shaari K, Israf DA, Stanslas J, Yusuf UK, et al. A labdane diterpene glucoside from the rhizomes of Curcuma mangga. J Nat Prod 2005;68(7):1090-3.

6. Ruangsang P, Tewtrakul S, Reanmongkol W. Evaluation of the analgesic and anti-inflammatory activities of Curcuma mangga Val and Zijp rhizomes. J Nat Med 2010;64(1):36-41.

7. Karsono AH, Tandrasasmita OM, Tjandrawinata RR. Molecular effects of bioactive fraction of Curcuma mangga (DLBS4847) as a downregulator of $5 \alpha$-reductase activity pathways in prostatic epithelial cells. Cancer Manag Res 2014;6:267-78.

8. Abas F, Lajis NH, Israf DA, Khozirah S, Kalsom YU. Antioxidant and nitric oxide inhibition activities of selected Malay traditional vegetables. Food Chem 2006;95:566-73. Available from: https://www. sciencedirect.com/science/article/pii/S0308814605001226.

9. Jantan I, Yassin MA, Chin CB, Chen LL, Sim NL. Anti-fungal activity of the essential oils of nine Zingiberaceae species. Pharm Biol 2003;41(5):392-7. Available from: https:/www.tandfonline.com/doi/ abs/10.1076/phbi.41.5.392.15941.

10. OECD. OECD Guideline for Testing of Chemicals. Vol. 423. Paris, France: Organization for Economic Cooperation and Development; 2001; Available from: https://www.ntp.niehs.nih.gov/iccvam/suppdocs/ feddocs/oecd/oecd g1423.pdf.

11. Kayarohanam S, Kavimani S. Acute and sub-acute toxicity study of aqueous methanolic leaf and bark extract of Dolichandrone atrovirens. Int J Pharm Pharm Sci 2015;7(6):63-65. Available from: https://www. innovareacademics.in/journals/index.php/ijpps/article/view/5540

12. de Pasquale A. Pharmacognosy: The oldest modern science. J Ethnopharmacol 1984;11:1-16.

13. Fajriaty I, Adnyana I, Fidrianny I, Acute and sub-chronic (28 days) repeated oral toxicity test of ethanol extract of lerak (Sapindus rarak DC) fruits in Wistar rats. Int J Pharm Pharm Sci 2014;6(11):487-92. Available from: http://www.innovareacademics.in/journals/index.php/ ijpps/article/view/4081.

14. Galgani J, Ravussin E. Energy metabolism, fuel selection and body weight regulation. Int J Obes (Lond) 2008;32 Suppl 7:S109-19.

15. Sharma V, Janmeda P. Protective assessment of Euphorbia neriifolia and its isolated flavonoid against $\mathrm{n}$-nitrosodiethylamine-induced hepatic carcinogenesis in male mice: A histopathological analysis. Toxicol Int 2014;21:37-43.

16. Serm LV, Lai HS, Wah HG, Aznam N, Yaacob H, Hassan MA, et al. Anti-proliferation and acute toxicity studies of Curcuma mangga rhizome. Nutrients 2014;6:4127-8. Available from: https://www. repository.um.edu.my/94185/1/nutrients-06-04115.pdf.

17. Meena AK, Rao MM, Preet K, Padhi MM, Singh A, Babu R. Comparative study on family zingiberaceae plants used in Ayurvedic drugs. Int J Pharm Clin Res 2010;2(2):58-60. Available from: https:// www.impactfactor.org/IJPCR/2/IJPCR, Vol2, Issue2,Article1.pdf. 